\title{
Impact of Political Violence in the Lives of Sri Lankan Preschool Children as Perceived by Their Preschool Teachers
}

\author{
Buddhiprabha D D Pathirana ${ }^{1}$ *
}

\section{ABSTRACT}

This study explores preschool teacher perceptions pertaining to the impact of political violence in the lives of Sri Lankan preschool children from May, 2000 to May, 2009. Participants were 25 preschool teachers from varied preschool communities. They were interviewed using a semi structured interview schedule. The analysis of the data conveyed that preschool teachers' perceptions could be divided into three main categories. 1 . Preschool teachers who perceived that preschool children were not at all to marginally affected by the political conflict $(\mathrm{n}=10), 2$. Preschool teachers who perceived that children were somewhat affected by the political conflict $(\mathrm{n}=06)$, 3. And preschool teachers who perceived that children were highly affected by political conflict $(\mathrm{n}=09)$. The preschool teachers reported that the impact of political violence varied from depressed affect to expressions of anger and irritability within the preschool children. Further, children who were exposed to multiple forms of violence were perceived to be more affected in comparison to children who were affected by political violence alone. Teachers also reported that the preschool children displayed sophisticated, age inappropriate and detailed awareness of weapons and children's play themes contained parodies of war and combat. The study also finds that teacher perceptions were correlated with the geographical location of the preschool as well as the teacher-children exposure to the combat. The findings of the study discuss the impact of political violence on young children in the continuum of Trauma Vs. Resilience.

Keywords: Preschool Children, Teachers, Impact, Perceptions, Political Violence

Childhood can be considered a dangerous phase taking into account the nature and intensity of violence children experience from different nested structures (home, school, neighborhood, television and country). One of these unfortunate forms is political violence that occurs due to conflict between nations or between identifiable groups within a nation, targeting children as victims, witnesses or aggressors for centuries (Staub, 1989; de Silva, 2003; Somasundaram, 1998; Das, 1990).

\footnotetext{
${ }^{1}$ Senior Lecturer in Psychology, Department of Philosophy \& Psychology, University of Peradeniya, Sri Lanka *Responding Author

(C) 2016 I B Pathirana; licensee IJIP. This is an Open Access Research distributed under the terms of the Creative Commons Attribution License (http://creativecommons.org/licenses/by/2.0), which permits unrestricted use, distribution, and reproduction in any Medium, provided the original work is properly cited.
} 
Organized forms of political violence including war, torture, rape, forceful recruitment of children as soldiers and various other child rights violations has been inflicted on Sri Lankan children during the past four decades, by wide-range of perpetrators, including militaries and Para-militaries (Somasundaram, 1998; Gunarathna, 1990; Das, 1990; de Silva, 2000; Keairns, 2003; Puvimanasinghe, Jeong-ho \& Voorhls, 2004; Lanka Library, 2007).

The present study explores the impact of political violence in the lives of preschool children from May, 2000 to May, 2009 during the time of civil war between the Government of Sri Lanka and The Liberation Tigers of Tamil Elam (LTTE) which ranged for almost two decades. During this period, civilians were casualties of war, landmines and bomb explosions in North as well as South. Public property including schools was destroyed.

Sri Lankan children have been particularly vulnerable group who suffered from repeated experiences of political violence such as loss/injury/separation of caregivers, displacement, and lack of food, poverty, domestic violence, abduction and school disruption/drop out (Gunarathna, 1990; Somasundaram, 2002; Puvimanasinghe, et al., 2004; Fernando \& Ferrari, 2011); their cumulative exposure to political violence leading to chronic mental health problems (Somasundaram, 2002; Fernando, Miller, \&Berger, 2010; Catani, Gewirtz, Wieling, Schauer, Elbert, \& Neuner, 2010).

Very young Sri Lankan children compared to older children, adolescents and adults were even more vulnerable to political violence as it posited several threats for them in comparison to adults and older children. Unlike adults and older children they were not able to physically protect themselves from the potentially dangerous effects of it. Since young children did not possess the communication skills to express their feelings and share experiences in comparison to older children their distress may have gone unnoticed by the caregivers and mental health professionals, in turn affecting their future wellbeing. Moreover, some caregivers may have believed that 'very young children' are not aware of what goes on around them or that they will forget what they experience' (Pathirana, 2011) since they do not have the cognitive capacity to understand it.

Therefore, very young children were even more vulnerable to the impact of political violence which prevailed in Sri Lanka. However, studies which investigated the impact of political violence on very young Sri Lankan children are almost non-existent in the Sri Lankan milieu. Few studies which exist provide either quantitative data (Pathirana, 2006) or did not exclusively explored the impact of political violence in the lived of very young Sri Lankan children (Fernando \& Ferrari, 2011). However, considering the importance of early experiences of young children on their later behavior, there is an urgency to examine the effects of political violence on young children. 
Hence, the aim of the present study is to explore the impact of prevailed political violence in the lives of very young Sri Lankan children as perceived by their preschool teachers.

\section{METHOD}

\section{Participants}

The study was carried out from May, 2000 to May, 2009, during the political conflict which prevailed in Sri Lanka. Data was collected using a semi structured interview questionnaire. Twenty five (18 to 60 years) preschool teachers from varied preschool communities (preschool in the plantation sector, rural \& urban preschools, Sinhala, English and Tamil medium preschools, model preschools funded by the government/ non- governmental organizations, private/ fee levying preschools, preschools of which disabled children were the predominant population, preschool in a street children community, a preschool in a fishing community, preschools in areas of which garment factory workers, security officers \& migrant mothers to the middle-east are the predominant population), belonging to 18 districts of Sri Lanka participated in the study. Nineteen preschool teachers were from South while six teachers were from North \& East of Sri Lanka.

\section{Instruments}

The research tool was part of a semi structured interview questionnaire which explored preschool teacher perceptions pertaining to aggression and prosocial behaviors of Sri Lankan preschool children. The preschool teachers were requested to provide instances of behaviors which they have observed in the preschool children within the past 6 months of the interview pertaining to political violence.

\section{Procedure}

All participants (preschool teachers) signed informed consent forms for confidentiality. During the interviews, researcher was attentive and assisted teachers in comprehending the interview questions. The data were collected during three measurement points. Based on the conflict which prevailed in Sri Lankan from May, 2000 to May, 2009 or the absence of it, these measurements points can be divided into three categories. Before ceasefire, during the ceasefire agreements (From December, 2001 to 2007) and after the ceasefire agreements between the Government of Sri Lanka and LTTE 
RESULTS

Table 01: Impact of political conflict on preschool children: Teacher Perceptions

\begin{tabular}{|l|l|l|}
\hline Category & Teacher profile & Children's Behavior \\
\hline $\begin{array}{l}\text { I - Children not at all to } \\
\text { marginally affected (n= 10) }\end{array}$ & $\begin{array}{l}\text { Preschool teachers living in } \\
\text { villages, plantation sector, } \\
\text { cities least affected by conflict }\end{array}$ & $\begin{array}{l}\text { No specific behavior } \\
\text { mentioned }\end{array}$ \\
\hline $\begin{array}{l}\text { II - Children somewhat } \\
\text { affected (n= 06) }\end{array}$ & $\begin{array}{l}\text { Preschool teachers living in } \\
\text { cities, mainly from Colombo }\end{array}$ & $\begin{array}{l}\text { Play themes involving } \\
\text { parodies of war and combat } \\
\text { (e.g. Playing soldiers Vs. } \\
\text { terrorists, playing bunkers) }\end{array}$ \\
\hline $\begin{array}{l}\text { III - Children highly affected } \\
\text { (n= 09) }\end{array}$ & $\begin{array}{l}\text { Preschool teachers from North } \\
\text { \& East }\end{array}$ & $\begin{array}{l}\text { Vigilant, resilient, fearful, } \\
\text { irritable and agitated }\end{array}$ \\
\hline
\end{tabular}

The analysis of the results conveyed that preschool teachers' perceptions could be divided into three main categories. 1. Preschool teachers who perceived that preschool children were not at all to marginally affected by the political conflict $(n=10)$, 2. Preschool teachers who perceived that children were somewhat affected by the political conflict $(\mathrm{n}=06)$, 3 . And preschool teachers who seemed to perceived that children were completely affected $(n=09)$.

Preschool teachers $(n=10)$ who perceived that children were not at all affected to least affected taught in village preschools, plantation sector or cities which were least affected by the conflict.

Preschool teachers $(n=6)$ who perceived that children were somewhat affected mainly came from preschools in Colombo. During the time of conflict the Colombo had high security zones with many check points. All those who passed through these check points were thoroughly searched. Also, bomb explosions were common and frequent phenomena in Colombo. As a result, the teachers reported that preschool children in their schools may also have been affected by the political conflict as they too were sometimes searched when they passed through these checkpoints or witnesses the repercussions of bomb explosions.

"Children in my preschool tell that they are asked to open and show their bags when they pass checkpoints. I think such incidents occur due to the conflict in the country, and due to such experiences children are aware that there is ongoing conflict in the country"

(Preschool teacher from a street children community, during the conflict)

Preschool teachers who taught in urban preschools (mainly Colombo, the capital of Sri Lanka) reported that children's play themes often contained parodies of war and combat using props such as toy blocks or tree sticks to depict guns, even though toy guns were not available in the

(c) The International Journal of Indian Psychology, ISSN 2348-5396 (e)| ISSN: 2349-3429 (p) | 186 
preschools to play soldiers. According to the preschool teachers, the children seem to divide themselves into two groups, playing soldiers and terrorists.

Though we do not have guns and such other toys in our preschool children play war games using whatever things they come across such as sticks, wooden blocks etc. they use those things as guns and say 'D'shoom D'shoom' (sound of a gun). I think this is because of the war.

(Preschool teacher from a Non Governmental Preschool)

Preschool teachers $(\mathrm{n}=9)$ who perceived that children were highly affected were from preschool in North \& East or taught in Colombo pre-schools and were actively involved in welfare of the preschools in North \& East. They reported that children were extremely vigilant of war and knowledgeable about weapons used by both army and the LTTE to the extent of possessing the ability to discriminate the weapons used by the Sri Lankan army from those used by the LTTE.

Once we went to a welfare camp in Anuradhapura taking food and other rations. At a distance we could hear the sounds of firing. Though we could not identify the difference between sounds, the preschool age children in the camp told us 'those are our Artees (meaning Artilleries fired by the Sri Lankan army), those are tigers' Artees (Artilleries fired by the LTTE). We did not know what 'Artees' were and asked the children and they were able to tell us.

- (Preschool Teachers from model preschool in Colombo)

The preschool teachers who perceived that children were highly affected by the prevailing political violence to the extent of being traumatized reported that the negative impact of violence varied from depressed affect to expressions of anger and irritability within the preschool children. They also reported that children were fearful, irritable, and agitated due to their experiences of political violence. Further, the preschool children were proclaimed to be experiencing nightmares and sleep disturbances which were attributed to their hearing and experiencing of bomb explosions, 'firing of mortars' (heavy artilleries) and gun fire.

I find children in my preschool are fearful, irritable and agitated. I think this is due to direct and indirect consequences of war. A girl in my preschool appears to be always disturbed. When I asked the mother for the reason she told me she used to hear and experience many negative consequences of war while she was expecting the girl.

(Preschool teacher from the East)

Some preschool teachers who perceived the children to be highly affected were also of the opinion that children had come to accept combat as triviaor events which were of no importance and become 'immune' to these events of combat. 
Our children in the North always see and hear shooting, massacres of humans, murders. Due to this children treat these events as trivial things. The reason is that they always see these with their own eyes, hear these with their ears and face these (experience them). I have experienced that due to political conflict even children are often subjected to harassment.

- (Preschool teacher form a conflict affected area in the East)

When preschool teachers were interviewed during the period of ceasefire, those who perceived that children were highly affected seemed to fear the occurrence of conflict more than those who were geographically far from it. The below excerpt indicate the weariness and fear of the teachers' who with high geographical proximity to the combat, pertaining to the occurrence of conflict.

We used to hear sounds of firing everyday and have shifted our preschool several times because it was not safe to teach small children when people are fighting. If war comes again we will not shift come what may, we are so tired of everything.

(Preschool teacher from the East, during the time of peace treaty)

Preschool teachers in the South were of the opinion that awareness pertaining to conflict and political violence was largely due to viewing and co-viewing of the television programs. They reported that children in their preschool classes frequently imitated advertisements which were often aired to promote recruitment of soldiers to the Sri Lankan army.

Preschool teachers interviewed during the peace treaty between the army and LTTE were of the opinion that in comparison to the period of combat preschool children's imitation of aggressive acts and enacting of play parodies of political conflict were less frequent. They attribute the children's escalation of aggressive acts to the conflict. They also said that children's vocabulary consisted of words such as AK 47, T56, bunker, tigers, battle tanks etc. during the political conflict, compared to post conflict days.

In the previous years (the interviews were conducted during the post conflict, peace treaty year) in children tried to shoot others during the interval (recess/free play time) using even a broom. During the interval (meaning recess) one of their favorite games was playing 'army camp'. Even if they crawled under the tires in the playground, they used to say we are in the camp, crawling to our bunkers.

(Preschool Teacher from Colombo preschool)

However, teachers perceived that children whose father's served in the Sri Lankan army did not seem to be more aware of the conflict. During the interviews teachers reported that some children whose fathers serve in the army were hardly aware of the fact that there is an ongoing

(C) The International Journal of Indian Psychology, ISSN 2348-5396 (e)| ISSN: 2349-3429 (p) | 188 
conflict in the country. This could be due to the fact that their families took extreme care to conceal this from the children considering the future consequences of reporting death or injury of the father.

On the other hand children who came from communities in which almost all the community members serve or served in the army were reported to be displaying intense aggressive behaviors. A preschool teacher who taught in a preschool in which the children were mainly from 'Ranviru' families in a 'Ranviru' village (village comprising of houses constructed for families of soldiers disabled, killed or missing in action by the Sri Lankan government) reported that in her preschool the children identified themselves with the soldiers in the Sri Lankan army perceiving army as the in-group and LTTE as the out group or the enemy and thus requiring to be killed and conquered. As a result, their play themes reported to have displayed frequent and complex war/combat parodies, with children imitating the role of soldiers in the Sri Lankan army pretending to kill those who personified the 'LTTE terrorists'. However, preschool teachers from North and East did not report play parodies of their children which maybe attributable fear and perceived discrimination of the preschool teachers.

Teacher reported that young children perceived to be experiencing multiple forms of violence (e.g. domestic, media, and community) displayed greater distress, intense and more frequent forms of aggression in comparison to the children who were exposed to political violence alone. Further, preschool teachers also reported that support received from the primary caregiver (specially mothers) and the extended family, emotional reaction and attitudes of the primary care givers pertaining to political violence impacted effect of political violence on young children. Children who had primary caregivers with mental health issue due to political violence were perceived to be more affected in comparison to those who viewed it as an issue which is temporary (i.e. which would be eventually over) and engaged in practices such as religious rituals or attended their respective places of religious worship. Teachers reported such caregivers created a sense of comfort within their children.

\section{DISCUSSION}

The aim of the present study was to explore the impact of political violence in the lives of young Sri Lankan children during the conflict: as perceived by their preschool teachers.

The results conveyed that teacher perceptions could be divided into three distinct categories. Teacher who perceived that preschool children were not at all affected by political violence which prevailed in the country, teachers who perceived that preschool children were moderately affected and teachers who perceived that preschool children were severely affected by the political violence. The preschool teachers who perceived that children were highly affected reported children demonstrating sophisticated awareness of weapons and displayed extreme 
distress and startle responses to due to their experience pertaining to political violence. These findings are in par with the research which convey the mental health consequences of political violence for children (Barenbaum, Ruchkin, \& Schwab-Stone, 2004; Betancourt \& Williams, 2008; Pathirana, 2006)

The study also finds that teacher perceptions were correlated with the geographical location of the preschool as well as the teacher-children exposure to the combat. Preschool teachers with more exposure to combat having a preschool located in a combat frequented areas perceived children to be highly affected by political violence in comparison to those who came from locations which were considerably away from it.

It should also be noted that the present study is limited by its sample size ( $\mathrm{n}=23)$. The sample is relatively small with heterogeneous beliefs about the effects of violence which makes the belief groups quite small, with six teachers in one group. Further, it failed to examine several philosophical issues which would have been worth exploring such as teachers' perceived 'sense of childhood lost' of the children they teach in comparison to their perceived sense of childhood as children exposed to political violence or not being exposed to it (i.e. Some participants would have experienced political violence as children while other did not; since incidents of political violence prevailed in Sri Lankan for several decades. Therefore, it would have been worth exploring teacher perceptions of their childhood free and not free of political violence affected their perception of children in their preschools experiencing it).

Even though the main focus of the study was children impacted by political violence some parts of the study were conducted immediately after Tsunami. As previous studies convey that exposure to conflict creates a greater impact than Tsunami (Somasundaram, 2007) while other convey that war, Tsunami and family violence significantly contribute poor child adaptation (Catani et al, 2010). Hence, teacher's perception of young Sri Lankan children impacted by natural and manmade disaster would have added valuable information, the study failed to gather this data due to time constrains and consider the absence of this data to be loss of valuable information.

The strength of this study lies in its diversity of the participants (children's affected by political violence in different parts of the country, collected from a diverse sample of preschool teachers). The data was gathered during several measurement points during varied phases of conflict thus conveying broader perspective on the impact of political conflict in the lives of very young Sri Lankan children as perceived by their preschool teachers.

The present study raises several important issues in the continuum of trauma and resilience pertaining to very young children affected by political violence in the Sri Lankan milieu. Some 
children manage to adapt and recover, showing resilience, while others did not. However, resilience has only recently been applied to young children (ages0-5) even though it has been reviewed in the psychology literature for several decades. Masten (2007) describes resilience as "ordinary magic," conveying that resilience does not require something rare or special, a finding the present study confirms. Literature also reports that very young children who are able to "bounce back" after adversities have more resources within themselves, their families (Masten, 2007) and communities. Literature also lists a concept labeled as "minimal-impact resilience," a state which occurs when there is little or no disturbance in function following an acute traumatic event. Even though the present study briefly examined resiliency of young children from secondary source it also came up with similar findings.

The study also finds that children who received more emotional support from their primary caregiver and the extended family were perceived to be more resilient, while children whose primary caregiver's displayed negative affect and attitudes pertaining to political violence were perceived to be less resilient by their preschool teachers. Hence, this study recommends the understanding of protective process in the lives of young children affected by political violence while emphasizing the need for understanding the maternal protection and attachment relationships available to them.

The study makes several suggestions and recommendations to future research. First, it believes that future studies need to explore the Sri Lankan preschool teacher perceptions of political conflict on preschool children in the absence of a conflict to explore their perceptions pertaining to it (i.e. Do they perceive the impact to be more or less than what they perceived it to be during the conflict and immediately after conflict). Second, it is of the opinion that future studies need to explore in depth the specific factors which create resilience within one group of children and causes trauma within the others when both groups experience similar traumatic events such as ongoing trauma and cumulative traumatic experiences.

\section{Acknowledgments}

The author appreciates all those who participated in the study and helped to facilitate the research process.

\section{Conflict of Interests}

The author declared no conflict of interests.

\section{REFERENCES}

Barenbaum, J., Ruchkin, V., \& Schwab-Stone, M. (2004). The psychosocial aspects of children exposed to war: Practice and policy initiatives. Journal of Child Psychology and Psychiatry, 45(1), 41-62. 


\section{Impact of Political Violence in the Lives of Sri Lankan Preschool Children as Perceived by Their Preschool Teachers}

Betancourt, T. S. \& Williams, T. (2008).Building an evidence base on mental health interventions for children affected by armed conflict. International Journal of Mental Health, Psychosocial Work and Counseling in Areas of Armed Conflict, 6(1), 39-56.

Catani, C., Gewirtz, A.H., Wieling, E., Schauer, E., Elbert, T., and Neuner, F. (2010).Tsunami, War, and Cumulative Risk in the Lives of Sri Lankan. School children. Child Development. Vol. 81 (4), 1176-1191

Das, V.(1990). “Our work to cry: Your work to listen.”In. Das, V. (Eds.).Mirrors of violence. Delhi: Oxford University Press.

de Silva, H. (2003). Power games in war and peace: The tragic impact of corruption, violence and impunity on the Sri Lankan child. Colombo, Sharp Graphic House (ISBN 10: 9559525719).

Fernando, C., \& Ferrari, M. (2011): Spirituality and Resilience in Children of War in Sri Lanka, Journal of Spirituality in Mental Health, 13 (1), 52-77.

Fernando, G.A., Miller, M.E., Berger, D.E. (2010). Growing Pains: The Impact of DisasterRelated and Daily Stressors on the Psychological and Psychosocial Functioning of Youth in Sri Lanka. Child Development.81 (4), pp 1192-1210.

Gunaratna, R. (1990). Sri Lanka a lost revolution: The inside story of the JVP. Kandy: Institute of Fundamental Studies

Jouriles, E.N., Murphy, C.M., \& O’Leary, K.D. (1989).Interpersonal aggression, marital discord, and child problems. Journal of Consultant Clinical Psychology, 57, 453- 455.

Keairns, Y.E. (2003). The voices of girl child soldiers Sri Lanka, Quaker United Nations Office. Retrieved on 14th of August, 2011, from http://www.quno.org/newyork/Resources/girlSoldiersSriLanka.pdf

Lanka Library, "Arantalawa massacre - June 2nd 1987". Retrieved on 11th of August, 2011, from, http://www.lankalibrary.com/phpBB/viewtopic.php?t=3345.

Masten, A.S. (2007). Resilience in developing systems: progress and promise as the fourth wave rises. Dev Psychopathol, 19, 921-930.

Pathirana, B.D.D \& Fernando, G. (2006). Teacher perceptions of ethnic violence on preschool children in Sri Lanka. In. Peradeniya University Research Sessions. November, 2006. University of Peradeniya.

Pathirana, B.D.D. (2006). Doctoral dissertation, “An inquiry into early violence/aggression and prosocial behaviors in preschool children in Sri Lanka to identify appropriate interventions”. University of Colombo, Sri Lanka

Pathirana, B.D.D. (2011). The cost of violence on children. In The Sri Lanka Journal of the Humanities. Vol. XXXVII (Numbers 1 \& 2).

Puvimanasinghe, S., Jeong-ho \&Voorhls (2004).An Exceptional Collapse of the Rule of Law: Told through stories by families of the disappeared in Sri Lanka, Colombo, Clear-Cut Publishing and Printing Co. 
Somasundaram, D. (1998). Scarred minds: The psychological impact of war on Sri Lankan Tamils. New Delhi: Sage Publications India Private Limited.

Somasundaram, D. (2002). Child soldiers: Understanding the context. British Medical Journal, 324, 1268-1271.

Somasundaram, D. (2007). Collective trauma in northern Sri Lanka: a qualitative Psychosocialecological study. International Journal of Mental Health Systems. 1 (1), 5, DOI: 10.1186/1752-4458-1-5. Retrieved from online on 14th August, 2011, http://www.springerlink.com/content/975106225482xr23/

Staub, E. (1989). The roots of evil: The origins of genoside and other group violence. New York: Cambridge University Press.

How to cite this article: B Pathirana (2016), Impact of Political Violence in the Lives of Sri Lankan Preschool Children as Perceived by Their Preschool Teachers, International Journal of Indian Psychology, Volume 3, Issue 4, No. 59, ISSN 2348-5396 (e), ISSN: 2349-3429 (p), DIP: 18.01.076/20160304, ISBN: 978-1-365-26307-1

(c) The International Journal of Indian Psychology, ISSN 2348-5396 (e)| ISSN: 2349-3429 (p) | 193 